\title{
Efficiency of pozzolan and sawdust as biofilter in the treatment of wastewater
}

\author{
B. Ouadi ${ }^{1}$ (1) A. Bendraoua ${ }^{3} \cdot$ N. Boualla ${ }^{1} \cdot$ M. Adjdir $^{2}$
}

Received: 7 August 2019 / Accepted: 6 May 2020 / Published online: 20 May 2020

(c) The Author(s) 2020

\begin{abstract}
Wastewater can offer a favorable solution for wastewater treatment. This work reviews series of filters with different particle sizes, namely pozzolan and sawdust, as an alternative for wastewater treatment. A permeability coefficient was determined for each filter. The biofilm was prepared by passing a stream of wastewater containing bacteria through different filters separately. The purification of wastewater was performed on the biofilm with different particles sizes. The results show an inverse relationship between the permeability coefficient and the contact time that affects the efficiency of the filtration. Filtration efficiency yield is around 85-94\% for chemical oxygen demand (COD) and around 92-97\% for biological oxygen demand (BOD). High efficiency in removing some minerals is also observed by bacteria. The biofilm prepared from wastewater seems to be an efficient agent to filter wastewaters in particular rural areas. The formation of biofilms has significantly reduced bacterial activity and heavy metal content.
\end{abstract}

Keywords Pozzolan · Sawdust $\cdot$ Biofilm $\cdot$ BOD $\cdot$ COD $\cdot$ Wastewater $\cdot$ Heavy metals $\cdot$ Physicochemical parameters · Bacterial deposition

\section{Introduction}

The world has become threatened with war, especially in the Middle East, due to the scarcity of clean water resources and the increasing demands for it. Requirements for clean water have increased with population growth, rapid urbanization, misuse of water resources and climate disruption creating a global issue of great concern. Of the seven billion people globally, over $15 \%$ do not have access to adequate freshwater for a healthy life. Increasing water contamination from the discharge of water-borne pathogens, inorganic pollutants, such as arsenic, selenium and heavy metals (e.g., cadmium,

\section{B. Ouadi}

brahimusto@gmail.com; brahim.ouadi@univ-usto.dz

1 Laboratory Materials, Soil and Thermal, Department of Civil Engineering, University of Science and Technology, USTO-MB, 31000 Oran, Algeria

2 Department of Engineering Process, Faculty of Technology, University of Saida, Saida, Algeria

3 Laboratory Organic Synthesis, Physical-Chemical and Environment, Department Chemistry, University of Science and Technology - Mohamed BOUDIAF-, USTO-MB, 31000 Oran, Algeria lead, mercury and chromium), chemicals used in agriculture, human and animal pharmaceutical derivatives and endocrine disrupters has exacerbated the problem (Sheikh et al. 2019). Estrogens are one of the micro-pollutants in wastewater which are excreted by all humans and animals. These estrogen hormones have detrimental effects on water living organisms (Roudbari and Rezakazemi 2018). The treatment of wastewater is considered as a major priority due to the lack of natural sources of water. Organic wastes are serious problem of wastewater; different techniques and methods are used to purify the wastewater from organic and inorganic pollutants. These pollutants are produced from distillery, paper, textile and tannery effluents...etc. Biofilm is one of the most important biological processes of waste organic treatment (Omri et al. 2013). Successful applications of this technology have been reported in wastewater treatment, petrochemical, textile and tobacco industries (Leiknes and Degaard 2001; Cogan and Keener 2004). There are several benefits of using biofilm in wastewater treatment system in comparison with suspended growth systems, such as flexible procedures, smaller space demand, lower hydraulic retention time, increased resiliency, higher biomass retaining period, increased active biomass clusters, improved recalcitrant substance degradation as well as decreased rate in microbial 
proliferation (Shahot et al. 2014). Apart from that, the application of biofilm systems also increases the ability to control the frequency of reaction and population mechanism (Borkar et al. 2013). The Biofilm is formed and grown through a five-stage process (Cogan and Keener 2004). The application of fixed and moving bed processes is distinguished by the quality of the support components on which biofilm is configured on static platforms such as rocks, plastic profiles, sponges, granular carriers or membranes. Membrane bioreactor (MBR) for wastewater treatment is an effective process which can be used for municipal and industrial wastewaters (Rezakazemi et al. 2018a). Also, large quantities of industrial wastewater are produced annually in the world and there are many methods of treatment including ultrasound, the most important of which is biological treatment through the biological membrane (Rezakazemi et al. 2018b). This project can be embodied in the field especially in small communities such as villages, rural areas and even small cities. The main subject of this attempt is a comparison study of the efficiency between two natural materials as biofilm filter of bacterial and heavy metals.

\section{Materials and methods}

\section{Study materials}

\section{Wastewater}

Wastewater samples were collected after physical treatment from the Karma wastewater treatment plant (OranAlgeria).The different experimental work was based on the physicochemical and bacteriological analyses carried out at the level of the laboratory of Water and Sanitation Society of Oran (SEOR), Laboratory Organic Synthesis, Physical-Chemical and Environment (Univ. USTO-MB) and Laboratory Materials, Soil and Thermal (Univ. USTOMB) (Tables 1, 2).

\section{Pozzolan}

Pozzolan was obtained from natural deposits in northwest of Algeria (Bouhamidi Source situated at about $100 \mathrm{~km}$ from Oran). Different chemical composition and characteristic properties of pozzolan are presented in Tables 3, 4 and 5.

\section{Wood sawdust}

Wood sawdust is a solid residue, which is generated in the timber industry (Couto et al. 2012).The result of general analysis for broken wood from different trees under normal conditions shows the following composition: $40 \%$ of water, $1 \%$ of organic solids or ash and $59 \%$ of the elements capable of inflammation or oxidization. These elements are in dissimilar kinds of wood as: $29.5 \%$ carbon, $3.5 \%$ hydrogen, $26 \%$ oxygen and nitrogen (Meniai 2012).

Soils nature has a big effect on the ash's chemical composition that forms it, because nature and minerals quantity that form the ash differ from a place to another (in trees' different parts) with different parts in trees. These are also variation depending on seasons.

\section{Preparation of materials}

- Grinding and sifting pozzolan to obtain diameters ranging between $5-8 \mathrm{~mm}$ and $8-12.5 \mathrm{~mm}$.

Table 1 Analytical methods and apparatus used

\begin{tabular}{ll}
\hline Parameter & Method and apparatus \\
\hline Physicochemical & Analyzer multiparameter portable Mark Electrical Hanna instrument model HI 9811 \\
$\mathrm{pH}$ & Analyzer multiparameter portable Mark Electrical Hanna instrument model HI 9811 \\
Conductivity & Thermometers din 12775 \\
$\mathrm{~T}$ & Permeability meter \\
$\mathrm{K}$ & Thermoreactor SR3000/photoLab-S6 \\
$\mathrm{COD}$ & Manometric BOD Measuring Instrument-IS 602 \\
BOD & Ramp by filtration (oven at $\left.105{ }^{\circ} \mathrm{C}\right)$ \\
Suspended solids & Atomic absorption spectrometer/Automated novAA ${ }^{\circledR} 400$ P from Analytik Jena. HI 83200 Multiparameter \\
Heavy metals & Bench Photometer Hanna instrument \\
& \\
Bacteriological & Membrane filtration method. SEOR Laboratory \\
Coliformes. T & Membrane filtration method. SEOR Laboratory \\
E. coli & Membrane filtration method. SEOR Laboratory \\
Enterococcus & Membrane filtration method. SEOR Laboratory \\
Clostridium &
\end{tabular}


Table 2 Physicochemical and bacteriological parameter of wastewater (samples after physical treatment only)

\begin{tabular}{|c|c|c|c|c|c|c|}
\hline Parameter & & Error & P1 (09/07/2018) & P2 (19/07/2018) & S1 (03/09/2018) & S2 (13/09/2018) \\
\hline \multicolumn{7}{|l|}{ Physicochemical } \\
\hline $\mathrm{pH}$ & & \pm 0.02 & 7.16 & 7.57 & 7.55 & 7.48 \\
\hline $\mathrm{T}$ & $\left({ }^{\circ} \mathrm{C}\right)$ & \pm 0.02 & 27 & 23 & 28 & 26.2 \\
\hline Conductivity & $(\mu \mathrm{S} / \mathrm{cm})$ & \pm 0.02 & 2550 & 2750 & 2680 & 2570 \\
\hline Suspended solids & $(\mathrm{mg} / \mathrm{l})$ & \pm 0.15 & 20 & 48 & 59 & 31 \\
\hline $\mathrm{NO}_{2}^{-}$ & $(\mathrm{mg} / \mathrm{l})$ & \pm 0.04 & 30 & 12 & 7.25 & 6.7 \\
\hline $\mathrm{PO}_{4}^{-3}$ & $(\mathrm{mg} / \mathrm{l})$ & \pm 0.01 & 16.7 & 5.2 & 2.5 & 3.5 \\
\hline $\mathrm{Cu}^{+2}$ & $(\mathrm{mg} / \mathrm{l})$ & \pm 0.02 & 2.903 & 1.421 & 3.441 & 1.300 \\
\hline $\mathrm{SO}_{4}^{-2}$ & $(\mathrm{mg} / \mathrm{l})$ & \pm 0.05 & $>100$ & $>100$ & $>100$ & $>100$ \\
\hline $\mathrm{Fe}$ & $(\mathrm{mg} / \mathrm{l})$ & \pm 0.04 & 2.11 & 1.76 & 1.8 & 0 \\
\hline $\mathrm{Cr}^{+3}$ & $(\mathrm{mg} / \mathrm{l})$ & \pm 0.005 & 0.396 & 0.467 & 0.412 & 0.385 \\
\hline $\mathrm{Zn}^{+2}$ & $(\mathrm{mg} / \mathrm{l})$ & \pm 0.03 & 0.451 & 0.645 & 0.535 & 0.440 \\
\hline $\mathrm{Pb}^{+2}$ & $(\mathrm{mg} / \mathrm{l})$ & \pm 0.005 & 0 & 0.1 & 0.43 & 2.04 \\
\hline $\mathrm{Cd}^{+2}$ & $(\mathrm{mg} / \mathrm{l})$ & \pm 0.005 & 0.11 & 0.07 & 0 & 0.12 \\
\hline $\mathrm{Ni}^{+2}$ & $(\mathrm{mg} / \mathrm{l})$ & \pm 0.01 & 2.4 & 2.1 & 2.201 & 2.315 \\
\hline \multicolumn{7}{|l|}{ Bacteriological } \\
\hline Coliformes. T & $(\mathrm{CFU} / \mathrm{ml})$ & \pm 0.42 & 98 & 73 & 9900 & 9000 \\
\hline E. coli & $(\mathrm{CFU} / \mathrm{ml})$ & \pm 0.40 & 98 & 73 & 9900 & 9000 \\
\hline Enterococcus & $(\mathrm{CFU} / \mathrm{ml})$ & \pm 0.43 & 38 & 70 & 48 & 40 \\
\hline Clostridium & $(\mathrm{CFU} / \mathrm{ml})$ & \pm 0.23 & 8 & 4 & 10 & 8 \\
\hline
\end{tabular}

P1: wastewater sample after physical treatment of the biofilm industry on Pozzolan

P2: a sample of wastewater after physical treatment to pass it into a filter made from Pozzolan

S1: wastewater sample after physical treatment of the biofilm industry on sawdust

S2: a sample of wastewater after physical treatment to pass it into a filter made from sawdust

Table 3 Chemical oxide composition of pozzolan

\begin{tabular}{lllllllll}
\hline Composition & $\mathrm{SiO}_{2}$ & $\mathrm{CaO}$ & $\mathrm{Fe}_{2} \mathrm{O}_{3}$ & $\mathrm{MgO}$ & $\mathrm{Al}_{2} \mathrm{O}_{3}$ & $\mathrm{SO}_{3}$ & $\mathrm{Cl}$ & Loss on ignition \\
\hline Percentages (\%) & 45.21 & 9.99 & 9.84 & 4.38 & 17.85 & n.d & n.d & 3.91 \\
\hline
\end{tabular}

$n . d$ not defined

Table 4 Different characteristic properties of pozzolan

\begin{tabular}{ll}
\hline Porosity (\%) & $60-70$ \\
$\mathrm{pH}$ & $5.6-7$ \\
Density & $0.13-0.8$ \\
$\begin{array}{l}\text { Proportion of water } \\
\text { retention (\%) }\end{array}$ & $19-20$ \\
Blanks coefficient & $9.1-23$ \\
Chemical reaction & 0 \\
\hline
\end{tabular}

- Sifting the sawdust to obtain the diameters between 5-8 $\mathrm{mm}$ and $8-12.5 \mathrm{~mm}$.

- The above materials are washed with deionized water and dried to avoid any blockages caused by very small granules.

- The permeability coefficients $(k)$ are calculated (fixed charge of free surface) for pozzolan and sawdust for different diameters (5-8 and 8-12.5) $\mathrm{mm}$, and the results are shown in Table 6.
Table 5 Mineral composition of pozzolan expressed on weight \%

\begin{tabular}{ll}
\hline Counts & $\begin{array}{l}\text { Percent- } \\
\text { age }(\%)\end{array}$ \\
\hline Wollastonite.1\TAIRG & 30 \\
Augite, aluminian & 29 \\
Silicon oxide & 14 \\
Magnesium aluminum silicon oxide & 10 \\
Pyrope, ferroan & 7 \\
Pigeonite & 6 \\
Silicon oxide & 4
\end{tabular}

The equipment used for this experiment is given as follows:

- Wastewater basin.

- A small water pump. 
Table 6 Different experimental parameters results

\begin{tabular}{|c|c|c|c|c|c|c|c|c|c|}
\hline \multirow[t]{2}{*}{ Solids } & \multirow[t]{2}{*}{ Diameter $(\mathrm{mm})$} & \multirow{2}{*}{$\begin{array}{l}\text { Permeability } \\
(\mathrm{K})(\mathrm{cm} / \mathrm{s}) \\
\pm 0.35\end{array}$} & \multicolumn{2}{|c|}{ Before treatment } & \multicolumn{2}{|c|}{ After treatment } & \multicolumn{2}{|c|}{$\begin{array}{l}\text { Treatment } \\
\text { yield (\%) }\end{array}$} & \multirow{2}{*}{$\begin{array}{l}\text { Temperature of } \\
\text { experimental } \\
\text { environment } \pm 0.5\end{array}$} \\
\hline & & & $\mathrm{BOD} \pm 0.5$ & $\mathrm{COD} \pm 0.13$ & $\mathrm{BOD} \pm 0.5$ & $\mathrm{COD} \pm 0.13$ & BOD & $\mathrm{COD}$ & \\
\hline \multirow[t]{2}{*}{ Pozzolan } & $5-8$ & 8.12 & 210 & 612 & 6 & 36 & 97 & 94 & 25 \\
\hline & $8-12.5$ & 9.88 & 350 & 670 & 24.5 & 80 & 93 & 88 & 24 \\
\hline \multirow[t]{2}{*}{ Sawdust } & $5-8$ & 9.70 & 380 & 718 & 15 & 64 & 96 & 91 & 26 \\
\hline & $8-12.5$ & 13.04 & 320 & 690 & 25.5 & 103 & 92 & 85 & 23.5 \\
\hline $\begin{array}{l}\text { Pozzolan + Saw- } \\
\text { dust }\end{array}$ & $5-8 / 8-12.5$ & 9.80 & 320 & 702 & 16 & 77 & 95 & 89 & 26 \\
\hline
\end{tabular}

- Connecting pipes diameter of $5 \mathrm{~mm}$.

- Water sprinkler that allows the water to be sprayed evenly on the surface of the material.

The biofilter model has the following dimensions:

- Cylinder height of $45.5 \mathrm{~cm}$; inside diameter of $11.5 \mathrm{~cm}$; outer diameter of $12.5 \mathrm{~cm}$; and surface area of $103.81 \mathrm{~cm}^{2}$. The bottom of the cylinder is a perforated aluminum that allows the passage of water and air. The height of the material inside is $30 \mathrm{~cm}$.

- Flow meter is fixed to a rate of $1.4 \mathrm{~cm}^{3} / \mathrm{s}$.

\section{Phase I Biomembrane culture}

The wastewater used in this study is brought from the municipal wastewater treatment plant, and it has beforehand undergone a physical treatment (P1 and S1). The air bubbles are removed from the tank that contains the wastewater to prevent any oxidation or other interactions. The biofilms are prepared by passing the wastewater through different materials (pozzolan and sawdust) under different diameters of $5-8 \mathrm{~mm}$ and $8-12.5 \mathrm{~mm}$ separately. The wastewater is mixed with a solution of glucose $(1 \mathrm{~g} / \mathrm{l})$ to feed and increase the bacteria population. The mixture was passed into a glass cylinder with a different material height of $30 \mathrm{~cm}$ separately under a flow rate of $1.4 \mathrm{~cm}^{3} / \mathrm{s}$. The whole system is left in rotation in a closed circle for $8 \mathrm{~h} /$ day to provide oxygen to bacteria. After that, the whole system is brought to the temperature of $37{ }^{\circ} \mathrm{C}$ in an oven for the remaining hours. The operation is repeated daily until 10 days (Fig. 1).

\section{Phase II Measuring treatment yield}

Raw wastewater (P2 and S2) is passed into the biofilm prepared with different diameters under the flow rate of $1.4 \mathrm{~cm}^{3} / \mathrm{s}$ and speed of $0.22-0.44 \mathrm{~cm} / \mathrm{s}$. The BOD and COD of wastewater are measured before and after the treatment (Table 6).

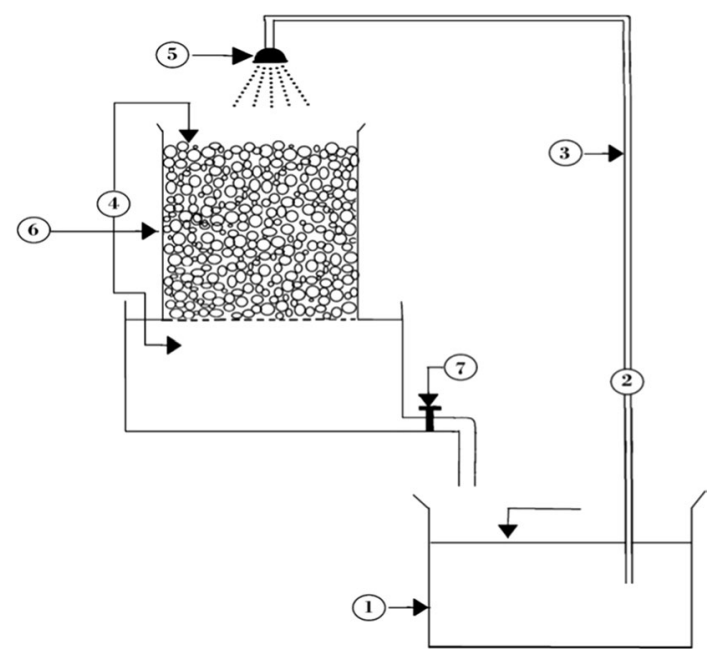

Fig. 1 Biofilm culture: 1. wastewater basin, 2. pump, 3. tubes, 4. air, 5. sprinkler. 6 . The material cylinder allows water to pass from the below: 7. Fauce

\section{Phase III Measuring the concentration of metal removal}

We took diameters of 5-8 for both sawdust and pozzolan each separately as they produced the best yield of BOD and COD. As shown in Table 6, we measured physicochemical properties as well as heavy metal concentrations in addition to bacterial activity before and after the wastewater treatment in the model (Table 7; Fig. 2).

\section{Results and discussions}

The speed is determined between 0.8 and $1.6 \mathrm{~m} / \mathrm{h}$ that is equal to $0.22-0.44 \mathrm{~cm} / \mathrm{s}$. After doing all the tests, we came up with the following results.

As results, it is noticed that the effect of particle size in the same material plays an important role in the yield of BOD and COD after treatment. The particle size ranging between 5 and $8 \mathrm{~mm}$ gives a yield greater than that given by 8 and $12.5 \mathrm{~mm}$. These results are in agreement with the 
Table 7 Physicochemical and bacteriological parameters of wastewater (before and after the treatment)

\begin{tabular}{|c|c|c|c|c|c|c|}
\hline Parameter & & Error & $\mathrm{P} 2$ & P3 & $\mathrm{S} 2$ & S3 \\
\hline \multicolumn{7}{|l|}{ Physicochemical } \\
\hline $\mathrm{pH}$ & & \pm 0.02 & 7.57 & 7.76 & 7.48 & 7.88 \\
\hline $\mathrm{T}$ & $\left({ }^{\circ} \mathrm{C}\right)$ & \pm 0.02 & 23 & 24.5 & 26.2 & 25.3 \\
\hline conductivity & $(\mu \mathrm{S} / \mathrm{cm})$ & \pm 0.02 & 2750 & 2680 & 2570 & 2413 \\
\hline Suspended solids & $(\mathrm{mg} / \mathrm{l})$ & \pm 0.15 & 48 & 69 & 31 & 53 \\
\hline $\mathrm{NO}_{2}^{-}$ & $(\mathrm{mg} / \mathrm{l})$ & \pm 0.04 & 12 & 6 & 6.7 & 0.8 \\
\hline $\mathrm{PO}_{4}^{-3}$ & $(\mathrm{mg} / \mathrm{l})$ & \pm 0.01 & 5.2 & 2.11 & 3.5 & 1.3 \\
\hline $\mathrm{Cu}^{+2}$ & $(\mathrm{mg} / \mathrm{l})$ & \pm 0.02 & 1.421 & 0.230 & 1.300 & 0.576 \\
\hline $\mathrm{SO}_{4}^{-2}$ & $(\mathrm{mg} / \mathrm{l})$ & \pm 0.05 & $>100$ & $>100$ & $>100$ & $>100$ \\
\hline $\mathrm{Fe}^{+3}$ & $(\mathrm{mg} / \mathrm{l})$ & \pm 0.04 & 1.76 & 1.38 & 0 & 0 \\
\hline $\mathrm{Cr}^{+3}$ & $(\mathrm{mg} / \mathrm{l})$ & \pm 0.005 & 0.467 & 0.203 & 0.385 & 0.219 \\
\hline $\mathrm{Zn}^{+2}$ & $(\mathrm{mg} / \mathrm{l})$ & \pm 0.03 & 0.645 & 0.360 & 0.440 & 0.221 \\
\hline $\mathrm{Pb}^{+2}$ & $(\mathrm{mg} / \mathrm{l})$ & \pm 0.005 & 0.1 & 0.8 & 2.04 & 0.59 \\
\hline $\mathrm{Cd}^{+2}$ & $(\mathrm{mg} / \mathrm{l})$ & \pm 0.005 & 0.07 & 0.05 & 0.12 & 0.03 \\
\hline $\mathrm{Ni}^{+2}$ & $(\mathrm{mg} / \mathrm{l})$ & \pm 0.01 & 2.1 & 1.02 & 2.315 & 1.178 \\
\hline \multicolumn{7}{|l|}{ Bacteriological } \\
\hline Coliformes. T & $(\mathrm{UCF} / 100 \mathrm{ml})$ & \pm 0.42 & 73 & 8 & 9000 & 7600 \\
\hline E. coli & $(\mathrm{UCF} / 100 \mathrm{ml})$ & \pm 0.40 & 73 & 8 & 9000 & 7600 \\
\hline Enterococcus & $(\mathrm{UCF} / 100 \mathrm{ml})$ & \pm 0.43 & 70 & 52 & 40 & 23 \\
\hline Clostridium & $(\mathrm{UCF} / 100 \mathrm{ml})$ & \pm 0.23 & 4 & 0 & 8 & 5 \\
\hline
\end{tabular}

P2: sample of wastewater after physical treatment and being passed through a filter made of pozzolan S2: sample of wastewater after physical treatment and being passed through a filter made of sawdust P3: sample of wastewater after being passed through the filter made of pozzolan S3: sample of wastewater after being passed through the filter made of sawdust

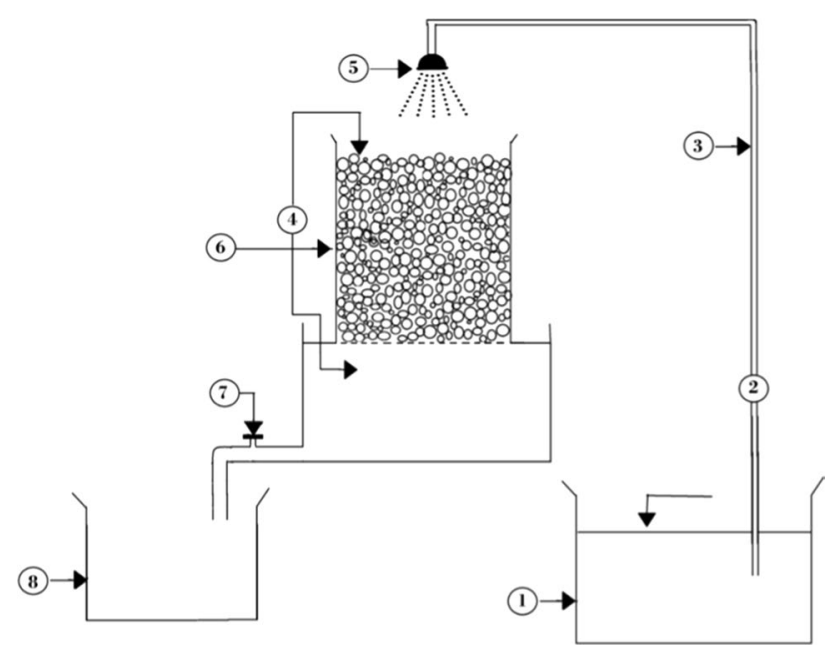

Fig. 2 Wastewater treatment by designed model (pozzolan, sawdust): 1. wastewater basin, 2. pump, 3. tubes, 4. air, 5. sprinkler. 6. The material cylinder allows water to pass from the below: 7. fauce, 8. treated water-receiving basin

permeability coefficient; the larger the particle size, the less friction and contact time between bacteria and water. This leads to a higher BOD and COD after treatment (Figs. 3, 4). In the case of the continued treatment during days or

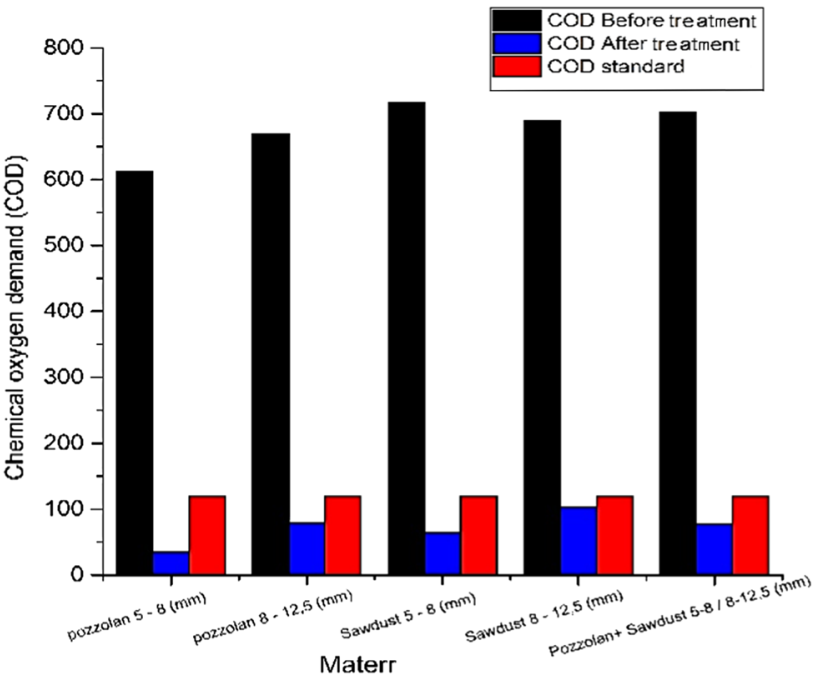

Fig. 3 Evolution of chemical oxygen demand (COD) depending on the particle size of the material. Standard COD value $=120 \mathrm{mg} / 1$

weeks for the diameters ranging between 5 and $8 \mathrm{~mm}$, it is noticed that the thickness of filter particles increases due to the significant breeding of bacteria and therefore the amount of oxygen entering the natural filter will be reduced, thus reducing the yield (Stoodley et al. 1998; Heydorn et al. 


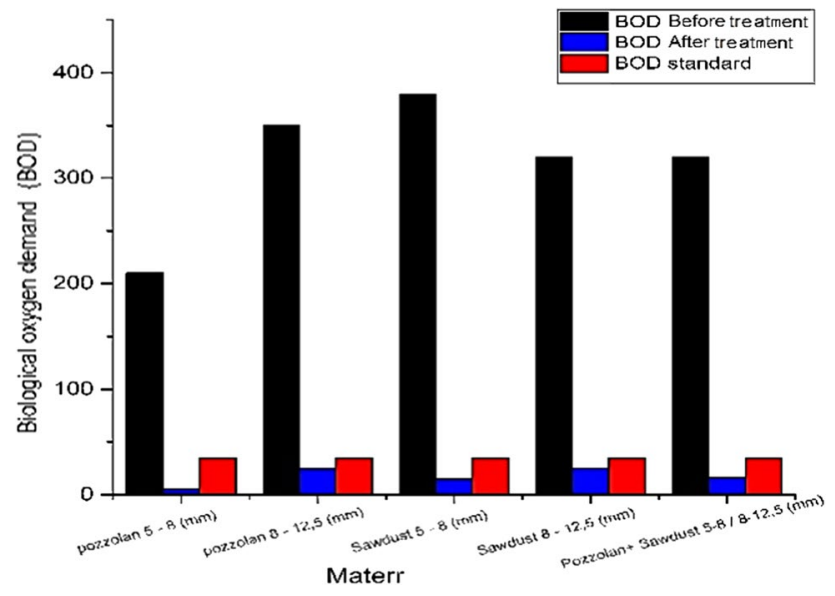

Fig. 4 Evolution of biological oxygen demand (BOD) depending on the particle size of the material. Standard BOD value $=35 \mathrm{mg} / 1$

2000); as confirmed by microscopically measured physical dimensions and visual comparison, the biofilms can take over 10 days to complete the biofilm structure. In our case, this duration was reduced by adding a solution of glucose $(1 \mathrm{~g} / \mathrm{l})$ and the whole system is brought to the temperature of $37{ }^{\circ} \mathrm{C}$ in an oven for the remaining hours to accelerate the bacteria growth. In the case of particle size distribution ranging between 8 and $12.5 \mathrm{~mm}$, the duration of occlusion is longer than that when the particle size is ranging between 5 and $8 \mathrm{~mm}$, which leads to the enhancement in cycle life of the filter. On the bases of the treatment yield by using the same diameters for these three materials, the obtained results present a high order of magnitude around $90 \%$. The slight difference can be attributed to the experimental error and the elemental composition of the filter. It is found that the permeability coefficient in the sawdust gives a significant increase when the particle size increase compared with the pozzolan. In the case when pozzolan and sawdust are mixed in the same proportion and with different diameters $8-12.5 \mathrm{~mm}$ and $5-8 \mathrm{~mm}$, respectively, the treatment yield of BOD and COD is still in the same order of magnitude around $90 \%$. It is concluded that the nature of the natural filter plays no role in improving the yield of BOD and COD. In contrast, the particle sizes give significant difference in the treatment efficiency of BOD and COD in favor of the small particle size. Within the framework of environmental conservation policy and the decrease in treatment process cost, it is preferable to use industrial waste such as sawdust as filter.

The COD and BOD yields obtained after treatment by using different filters with different particle sizes (Figs. 3, 4) give values under the standard values equal to $120 \mathrm{mg} / \mathrm{l}$ for COD and $35 \mathrm{mg} / \mathrm{l}$ for BOD, respectively, according to the Ministry of Water Resources of Algeria (Algerian Official Gazette No. 26, issued on April 23, 2006).
Figure 5 monitors the influence of particle size of different biofilters depending the contact time. It is noticed that when the particle size increases, the contact time of wastewater and the biofilter decreases. This can be explained by the relationship between permeability coefficient and particle size; when the particle size increases, the permeability coefficient increases. De Beer et al. (1994) demonstrated that the channels surrounding the cell clusters could increase the supply of oxygen (and other nutrients) to bacteria within the biofilm, thus relating structure to function. But the contact time decreases and thus the treatment yield decreases.

Figure 6 displays the results of treatment yield versus the particle sizes. As results, both BOD and COD yields decrease with the increase in particle size. These results can be explained by the statement found by De Beer et al. (1994).

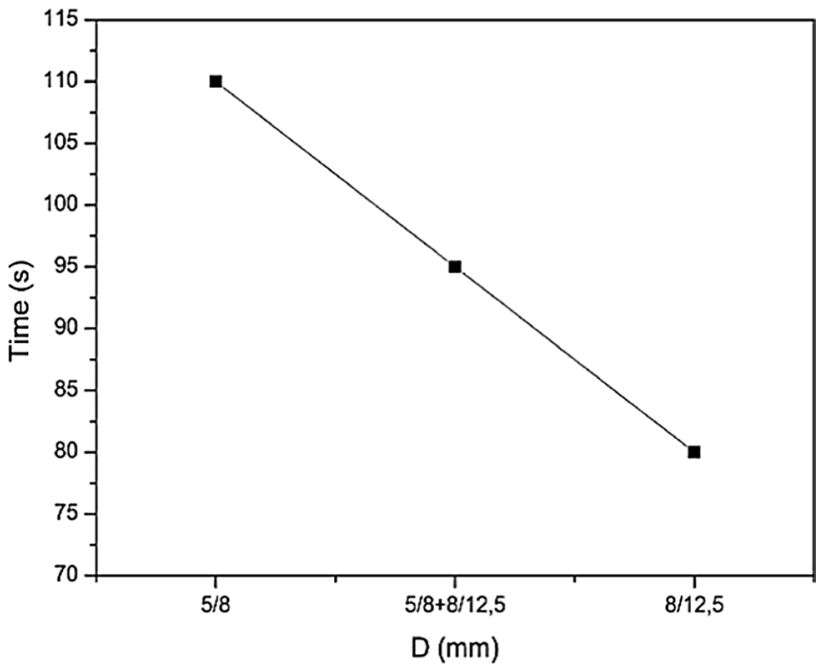

Fig. 5 Contact times depending on particle sizes

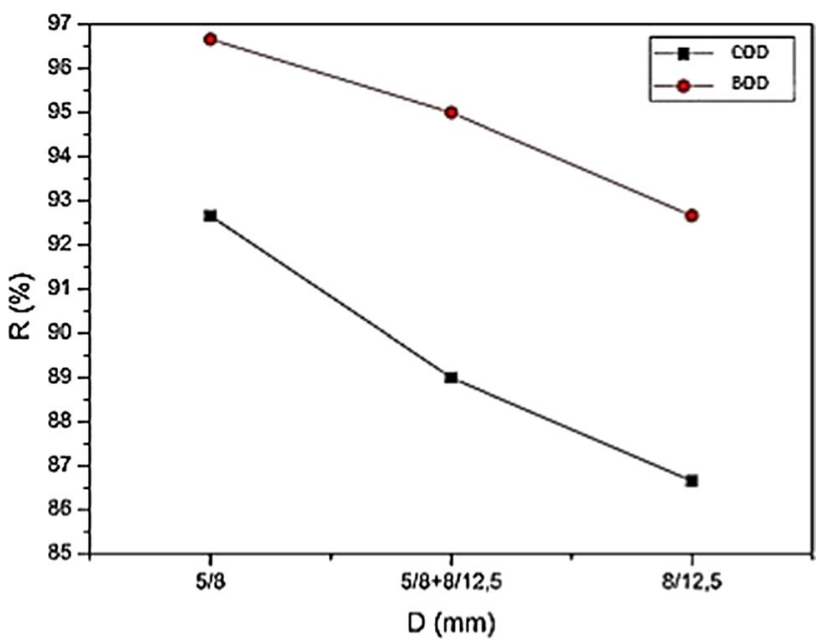

Fig. 6 Treatment yield versus the particle sizes 
The main goal of this study was to produce an effluent of better quality than that required by treatment standards.

The concentration of different parameters was periodically determined in the inlet and outlet of the biofilm bed, and then removal efficiency was calculated (Zhao and $\mathrm{Wu}$ 2018). Analysis of the removal results (Phase III) is shown in Table 7.

Results show that concentration of different element analyses decreased between inlet and outlet, following the biofilm treatment. It can be seen that the filters effectively reduced the different bacteriological and heavy metal elements and provided desired treatment.

Compared to the normative values $(>6.5$ and $<8.5)$, the urban rejection of Oran (Algeria) differs between 7.16 and 8.03. The waters have a slightly basic to basic character. It indicates absence of strongly acidic or alkaline spillages (Boualla 2014).

Temperatures between 22.5 and $28{ }^{\circ} \mathrm{C}$ (after or before treatment) never exceeded the recommended limit value $\left(30^{\circ} \mathrm{C}\right.$-Algerian Official Journal, 2006). The hottest waters are those of the Oran (Algeria) urban discharge: $28^{\circ} \mathrm{C}(\mathrm{S} 1)$.

The value of suspended solids measured after treatment exceed the national standard (Executive Decree 06-141 of April 19, 2006/Algerian Official Journal/23-04-2006) as the limit value for SS in liquid effluents (household, industrial and agricultural) a concentration of $35 \mathrm{mg} / \mathrm{l}$ (with values between 41 and $75 \mathrm{mg} / \mathrm{l}$ ) (Table 7). For the Oran (Algeria) urban effluent before treatment, only the $\mathrm{P} 1$ and $\mathrm{S} 2$ discharges comply with the standard (20-31 mg/l).

The comparison of our results with those of other studies carried out previously on the Oran littoral (Houma et al. 2004) shows a considerable decrease in the concentrations of the MES. In fact, in June 1998, the measured values reached $1885 \mathrm{mg} / \mathrm{l}$ at the level of the discharge and $1650 \mathrm{mg} / \mathrm{l}$ at $5 \mathrm{~m}$ toward the open sea. The evolution observed is the consequence of the recent efforts made by the public authorities in the treatment of wastewater (Remili and Kerfouf 2013).

In regard to the content of heavy metals, no value substantially exceeds the normative limit. Except in phase III, there was one outlier within: - Pb (pozzolan biofilm: P3-0.8 mg/l; S2-2.04 mg/l). This is due to the substantiation of the phosphate contents. As mentioned by Ruby et al. (1994) and Shi and Erickson (2000), the use of phosphates is considered an inexpensive and highly effective method for the treatment of lead-contaminated soils. Also, on these same samples, the nickel concentrations also fluctuate a lot, from 2.1 to $2.4 \mathrm{mg} / \mathrm{l}$ before treatment and between 0.982 and $1.523 \mathrm{mg} / \mathrm{l}$ after treatment. But the highest values remain well above the normative limit $(0.5-0.75 \mathrm{mg} / \mathrm{l})$. Removal appears to be dependent and a function of the filter physical and chemical characteristics. Heavy metals are useful and necessary for metabolic reactions and growth of bacteria, but with minimal concentrations, such as iron, cobalt, lead and copper.

In particular, copper plays a very necessary role for the growth of bacteria, helps in the synthesis of metallic proteins, enters into the synthesis of certain enzymes and helps in the transfer of electrons to oxidation and reduction processes. However, there is a section of heavy metals that has no biological effect, but it is toxic and deadly to bacteria, even if in small concentrations such as mercury, cadmium, silver and lead. It affects microbial clusters by acting on growth, shape and biochemical reactions, which inevitably leads to a decrease in biomass and thus negatively affects purification and disinfection processes. The practice of biological treatment is feverous to suspended solids growth (Table 7). The deletion of phosphate values is based on the succession of anaerobic and aerobic phases during biological treatment (Rejsek 2002).

Bacteria play a key role in the biogeochemical cycle in the environment and are used for the bioremediation of Ascontaminated groundwater. However, it is not yet known about how biofilm formations affect bacterial activities. The number of aerobic bacteria decreased with developed anaerobic conditions. Bacteria levels are decreased and scavenged by naturally occurring soil microorganisms in the pozzolan biofilm. It was associated with soils having the clay content and elevated $\mathrm{pH}$ values (Yaman 2003). The removal rates of bacteria were higher in the media with the finest grain sizes (pozzolan) as compared to the coarsest media under the same conditions (sawdust) (Ausland et al. 2002). Within the porous medium, there are areas where water can be trapped and immobile and therefore where water flows are zero. It is in these areas that bacteria can then diffuse and get trapped in addition to constriction areas where pores are too small to allow passage of cells (Truesdail et al. 1998, Jacobs 2007; Johnson et al. 2007).

\section{The mechanism of absorbing the minerals}

(a) The exclusion of the toxic metal by a permeability barrier:

These are nonspecific systems that prevent the entry of metal into the cell, either by alteration of membrane transport systems or by fixing the metal to the cell surface by components of the outer membrane of the wall or exopolysaccharides (Bruins et al. 2000).

(b) Intracellular or extracellular sequestration by cellular components which bind metals:

Outside a microorganism, metals can also be immobilized by complexation or precipitation. By-products of microbial metabolism such as $\mathrm{H} 2 \mathrm{~S}$ produced by sulfate-reducing bacteria or phosphate produced by Citrobacter lead to the precipitation of metals (Bruins et al. 2000).

(c) The enzymatic transformation of a metal: 
The mercury resistance conferred by the sea operon is the best known example. This operon present on transposants or plasmids exists in several bacterial species. The expression of the mer operon is regulated by MerR, a protein which binds to the operator/promoter of the operon and thus prevents its transcription. In the presence of mercury, MerR activates the expression of the detoxification system (Summers 1992).

(d) Active transport by expulsion systems:

It is the majority system involved in the resistance of microorganisms to heavy metals. It involves very specific membrane proteins that export toxic metals from the cytoplasm to the outside of the cell. In bacteria, two main active transport systems can be distinguished according to the energy source: the chemiosmotic transporters and the P-type ATPases.

Chemiosmotic transporters use a membrane potential as an energy source to activate the expulsion of toxic metals (Silver and Walderhaug 1992).

Type P ATPases represent an important class of membrane proteins which serve to maintain suitable ionic conditions by active translocation of cations across biological membranes (Lutsenko and Kaplan 1995).

\section{Conclusion}

In this study, the determination of the permeability coefficient and the treatment yield of natural materials with different particle sizes is represented.

As concluded in this study, as the surface area of the material increases, the density and concentration of the biological bacterial membrane increase and thus the effectiveness and the quality of treatment increase.

The performance and effectiveness were based on the efficiency in removing the required chemical oxygen (COD) and the required biological oxygen (BOD), and we found a high removal rate estimated as $85-94 \%$ for the COD and $92-97 \%$ for the BOD. Also elimination of heavy metals was done after treatment through the proposed model.

The yield of COD, BOD and heavy metals obtained after the treatment is less than the maximum values stipulated in Algerian laws and regulations. This is evident in Tables 6, 7 .

The biological treatment basins filled with natural materials such as pozzolan and sawdust are ideal, efficient and low cost for treatment of domestic wastewater. The appropriate experimental conditions such as standard flow, suitable height and the particle size of materials are suitable for bacteria growth. The biofilm formation significantly contributed to the removal of different polluted elements. The biofilters contribute to the removal of solids (Ahn and Jeongdong Choi 2016) and heavy metals. The final effluent passes through biofilm filter systems, which further treat toxic chemicals including organics and heavy metals.

The proposed process can be considered as low-cost process to treat different organic effluents released from industry.

This project can be embodied in the field, especially in small communities such as villages, rural areas and even small cities, in order to preserve the environment.

Funding No funding.

\section{Compliance with ethical standards}

Conflict of interest The authors declare that they have no conflict of interest.

Ethical approval This article does not contain any studies with human or animal subjects.

Informed consent Informed consent was obtained from all individual participants included in the study.

Open Access This article is licensed under a Creative Commons Attribution 4.0 International License, which permits use, sharing, adaptation, distribution and reproduction in any medium or format, as long as you give appropriate credit to the original author(s) and the source, provide a link to the Creative Commons licence, and indicate if changes were made. The images or other third party material in this article are included in the article's Creative Commons licence, unless indicated otherwise in a credit line to the material. If material is not included in the article's Creative Commons licence and your intended use is not permitted by statutory regulation or exceeds the permitted use, you will need to obtain permission directly from the copyright holder. To view a copy of this licence, visit http://creativecommons.org/licenses/by/4.0/.

\section{References}

Ahn Y, Jeongdong Choi J (2016) Bacterial communities and antibiotic resistance communities in a full-scale hospital wastewater treatment plant by high-throughput pyrosequencing. Water 8:580. https ://doi.org/10.3390/w8120580

Ausland G, Stevik TK, Hanssen JF, Kohler JC, Jenssen PD (2002) Intermittent filtration of wastewater-removal of fecal coliforms and fecal streptococci. Water Res 36(14):3507-3516

Borkar R, Gulhane M, Kotangale A (2013) Moving bed biofilm reactor :a new perspective in wastewater treatment. J Environ Sci Toxicol Food Technol 6(6):15-21

Boualla N (2014) New approach: exploitation of non-conventional water in irrigation. J Clim Change 1(2):62-67

Bruins MR, Kapil S, Oehme FW (2000) Microbial resistance to heavy metals in the environment. Ecotoxicity Environ Saf 45:198-207

Cogan N, Keener JP (2004) The role of the biofilm matrix in structural development. Math Med Biol J IMA 21(2):147-166

Couto GM, Dessimoni ALDA, Bianchi ML, Perígolo DM, Trugilho PF (2012) Use of sawdust Eucalyptus sp. in the preparation of activated carbons. Ciênc Agrotecnol 36(1):69-77 
De Beer D, Stoodley P, Roe F, Lewandowski Z (1994) Effects of biofilm structures on oxygen distribution and mass transport. Biotechnol Bioeng 43(11):1131-1138

Heydorn A, Nielsen AT, Hentzer M, Sternberg C, Givskov M, Ersbøll BK, Molin S (2000) Quantification of biofilm structures by the novel computer program COMSTAT. Microbiology 146(10):2395-2407

Houma F, Belkessa R, Khouider A, Bachari N, Derriche Z (2004) Étude corrélative des paramètres physico-chimiques et des données satellites IRS1C pour caractériser la pollution aquatique. Application à la baie d'Oran, Algérie. Revue des Sciences de l'eau 17(4):429-446. https://doi.org/10.7202/705541ar

Jacobs A (2007) Transport bactérien en milieux poreux: expérimentations et modélisation. Migration de bactéries issues de boues de STEP. University Avignon

Johnson WP, Li X, Yal G (2007) Colloid retention in porous media: mechanistic confirmation of wedging and retention in zones of flow stagnation. Environ Sci Technol 41:1279-1287

Leiknes T, Degaard H (2001) Moving bed biofilm membrane reactor (MBB-MR): characteristics and potentials of a hybrid process design for compact wastewater treatment plants. In: Proceedings of engineering with membranes, pp 52-57

Lutsenko S, Kaplan JH (1995) Organization of P-type ATPases: significance of structural diversity. Biochemistry 34:15607-15613

Meniai A (2012) The use of sawdust as by product adsorbent of organic pollutant from wastewater: adsorption of phenol. Energy Procedia 18:905-914

Omri I, Aouidi F, Bouallagui H, Godon J-J, Hamdi M (2013) Performance study of biofilter developed to treat $\mathrm{H}_{2} \mathrm{~S}$ from wastewater odour. Saudi J Biol Sci 20(2):169-176

Rejsek F (2002) Analyse des eaux: Aspects réglementaires et techniques. Centre régional de documentation pédagogique d'Aquitaine (CRDP), Bordeaux

Remili S, Kerfouf A (2013) Prolifération de l'algue Caulerpa racemosa dans les écosystèmes littoraux de l'Algérie: état des lieux et des connaissances. Physio-Géo 7:165-182

Rezakazemi M et al (2018a) High loaded synthetic hazardous wastewater treatment using lab-scale submerged ceramic membrane bioreactor. Chem Eng 62(3):299-304. https://doi.org/10.3311/ PPch. 11459
Rezakazemi et al (2018b) Wastewaters treatment containing phenol and ammonium using aerobic submerged membrane bioreactor. Chem Cent J 12:79. https://doi.org/10.1186/s13065-018-0450-1

Roudbari A, Rezakazemi M (2018) Hormones removal from municipal wastewater using ultrasound. AMB Express 8:91. https://doi. org/10.1186/s13568-018-0621-4

Ruby MV, Davis A, Nicholson A (1994) In situ formation of lead phosphate as a method to immobilize lead. Environ Sci Technol 28:646-654. https://doi.org/10.1021/es00053a018

Shahot K, Idris A, Omar R, Yusoff HM (2014) Review on biofilm processes for wastewater treatment. Life Sci J 11(11):1-13

Sheikh M et al (2019) Application of $\mathrm{ZnO}$ nanostructures in ceramic and polymeric membranes for water and wastewater technologies: a review. Chem Eng J. https://doi.org/10.1016/j.cej.2019.123475

Shi Z, Erickson LE (2000) Model development and simulation of in situ stabilization in lead-contaminated soils. In: 2000 conference on hazardous waste research, Denver (Colorado). https://doi. org/10.1016/s0304-3894(01)00212-6

Silver S, Walderhaug M (1992) Gene regulation of plasmid and chromosome-determined inorganic ion transport in bacteria. Microbiol Rev 56:195-228

Stoodley P, Dodds I, Boyle J, Lappin-Scott H (1998) Influence of hydrodynamics and nutrients on biofilm structure. J Appl Microbiol 85(S1):19S-28S

Summers AO (1992) Untwist and shout: a heavy metal-responsive transcription regulator. J Bacteriol 174:3097-3101

Truesdail S, Lukasik J, Farrah SR, Shah DO, Dickinson RB (1998) Analysis of bacterial deposition on metal (hydr)oxide-coated sand filter media. J Colloid Interface Sci 203:369-378

Yaman C (2003) Geotextiles as biofilm filters in wastewater treatment. Ph.D. thesis. Imam Adulrahman Bin Faisal University, Dammam, Saudi Arabia

Zhao D, Wu X (2018) Nanoparticles assembled $\mathrm{SnO}_{2}$ nanosheet photocatalysts for wastewater purification. Mater Lett 210:354-357

Publisher's Note Springer Nature remains neutral with regard to jurisdictional claims in published maps and institutional affiliations. 